$\mathrm{SAD} / \mathrm{JSR}$

Sosyoloji Araştırmaları Dergisi / Journal of Sociological Research

Cilt / Volume 18 Sayı / Number 1 (Nisan/April 2015) : (103-125)

\title{
THE ROLE OF NARRATIVE METHODS IN SOCIOLOGY: STORIES AS A POWERFUL TOOL TO UNDERSTAND INDIVIDUAL AND SOCIETY
}

\author{
Nuran EROL IŞIK
}

\begin{abstract}
The purpose in the article is to understand the role of the stories as well as storytelling in sociology. Rather than focusing on the significance of textual data based on narrativity, the author aims at underlining the role of the genres such as story, myth, irony, parable, drama, and aphorism, which are used in everyday life narratives. Sociology, as a discipline offering analyses at different levels of social life can borrow from these textual data in various different ways. In this sense, the ways in which narrativity and sociology come together would be related to the way we understand sociological methodology. Just as the lullabies are outcomes of collective references relatively independent of mothers' personal preferences, meta-narratives also have a characteristic of a multilayered texture embedded in our social and historical memory. In sum, firstly, the article will enlighten the intersection between the sociology and the narrative theory, second, examples of brief insights into popular cultural texts will be provided.
\end{abstract}

Keywords: Narrative, Storytelling, Sociology.

* Prof.Dr., İzmir Ekonomi Üniversitesi, Sosyoloji Bölümü 


\section{ANLATISAL YÖNTEMLERIN SOSYOLOJİDEKİ YERİ: BİREY VE TOPLUMU ANLAMAK İÇİN GÜÇLÜ BİR ARAÇ OLARAK ÖYKÜLER}

\section{ÖZET}

$\mathrm{Bu}$ makalede amaç anlatı ve öykü adı verilen dilbilimsel verilerin sosyoloji disiplini için önemini değerlendirmektir. Anlatıya dayanan metinlerin bilimsel veri olarak kabul edilebilmesi ile ilgili epistemolojik tartışmalardan çok, gündelik hayatta pekçok farklı mecrada karşılaştığımız öykü, efsane, kıssa, ironi, fikra, drama, aforizma gibi örneklerin sosyal hayat hakkında oluşturduğumuz anlam dünyası ile ilgisine dikkat çekmek hedeflenmektedir. Sosyoloji, toplumsal hayat ile ilgili farklı eksenlerde çözümlemeler yapan bir bilim dalı olarak anlatıya dayanan verilerden farklı şekillerde faydalanabilir. $\mathrm{Bu}$ anlamda anlatı ile sosyolojinin biraraya gelme biçimi sosyolojiye bakış tarzımızla da ilgili olacaktır. Ninnilerin anlatı açısından önemi nasıl bir annenin kişisel tercihinden bağımsız olarak kolektif referanslara sahip olması gibi, tarihsel toplumsal hafizamızda yer etmiş büyük anlatılar da bir o kadar derin katmanlar taşıyabilen niteliktedir. Kısaca, makalede öncelikle anlatı kuramı ve sosyolojinin kesişme noktası aydınlatılacak, daha sonra da öyküleştirme örneklerine dayanan popüler kültürel metinlerden örneklerle aydınlatılacaktır.

Anahtar Kavramlar: Anlatı, Öykü Anlatımı, Sosyoloji. 


\section{INTRODUCTION}

We live in narrative's moment (Maines, 1993). We live in a world people talk about their acts, feelings, and their people's lives within the framework of narrativity. Narrratives have become tools by which we reflect on ourselves as the makers of culture. We use different ways of telling our stories due to different experiences and expectations in our everyday life. As Barthes writes:

"Narrative is present in myth, legend, fable, tale, novella, epic, history, tragedy, drama, comedy, mime, painting stained glass windows, cinema, comics, news items, conversations. Moreover, under this almost infinite diversity of forms, narrative is present in every age, in everyplace, in every society; it begins with the very history of mankind and there nowhere is nor has been a people without narrative. All classes, all human groups, have their narratives" (Barthes, 1977: 79).

Human beings are makers of narratives which construct their selves. There is no dualism between self and society. There is a complex interplay between the society and self or selves, which are both storied productions. Narrative can also be seen as a telling, a performative event, and a process of making or telling a story. A story is an evaluation involving the narration of a series of events in a plotted sequence which unfolds in time (Andrews, et al. 2009). The discipline of sociology has been interested in communities and groups, as well as their stories. The fathers of sociology narrated social life in the $18^{\text {th }}$ century via narrations borrowed from different sources: the sacred books, people's own narrations, and institutional stories. Even the quantitative data used in sociological work constituted a narration describing a web of social relations and patterns. The question regarding the intersection of narratives and sociology has always been about a series of methodological debates, most of which have become clear after the so called 'linguistic turn.' This article presents introductory material so as to reveal the intersection between the narrrativity and sociological reality, which is among the deemphasized topics is social sciences. 
In contrast to the anti structuralist and anti-positivist agenda that has symbolized the "narrative turn" in the social sciences since the 1980s, a more uniquely sociological approach explored stories in the interactional, institutional, and political contexts of their telling. Scholars working in this vein accepted narrative as a powerful tool by focusing on the ways in which narrative competence is socially organized and unevenly distributed (Poletta, et al., 2011). Although the epistemological and methodological debates are not included in the scope of this article, one can claim that sociology and narrativity have become interrelated in terms of revealing the voices of the subjects as they talk about their experiences. We can be informed about the subjects' point of view as well as their interpretations about of the world via narratives which are constantly re-constructed. Thus, in this article, the purpose is (1) to evaluate the strengths of the narrative studies in understanding the sociological phenomena, and (2) to offer some brief insights into the ways in which popular media employs narrative as a form of storytelling.

\section{NARRATIVE AS A SOCIOLOGICAL TOOL TO UNDERSTAND SOCETY}

If we take a look at the current affairs in social life, it is not sufficient for us to fully understand the complexities of social processes, such as globalization and postmodernization by looking at the manifest functions of the institutions in the Mertonian sense. An engaged sociology would involve a sensual and full-bodied approach to knowing, and to practices of knowledge, by enriching life and allowing for possibilities and choices sociality offers (Game and Metcalfe, 1996). There are different issues covered by sociologists, such as the sociology of crime, poverty, popular culture, economy, politics, religion, social interaction, science, social stratification, modernity and postmodernity. These spheres of knowledge require us to become involved with the ways in which people narrate themselves and others. In other words, "because $(a)$ narrative texts are packed with sociological information and $(b)$ much of our empirical evidence is in narrative form, so that sociologists should be concerned with narrative" (Franzosi, 1998: 519). Works such as biographies, myths, travel writings, 
diaries, thrillers, fictional stories, soap operas, blogs, and bumper stickers, all depict some visions about various different sociological themes (disenchantment with the world, the changes in consumption patterns, transformation in gender identities, the rise of capitalism, the notions of alienation, anomie, etc) as well as meta-narratives themselves (socialism, the fall of the empire, the rise of the republic, the end of the capitalism, the end of the ideology, and many others). In other words, the so called idea of 'the men on the street' creates a sociological imagination which can be enlightened by discourses, rhetorical strategies, narratives, and other linguistic markers. By using such materials in their analyses, social scientists are not only capable of shedding light on unknown details of social life, but at the same time they are empowered to use the capacity of narratives in terms of giving voice to those who have been silenced.

Sociology is a discipline focusing on how patterns of actions shape people's lives. The premodern, modern, and postmodern ways of living offer different avenues for sociologists. In the process of studying the transformation from different phases of socio-historical lives, they have revealed how human societies and individuals living in these societies interact. As it is well known, the process of development of the sociology as a discipline was mainly about modernity. The first sociologists began to question how societies were held together, how social integration was possible, and how human beings constructed meaning making systems for themselves. In this framework, the fathers of sociology concluded that modernity is a complex condition which is based on ambivalences and ironies. In other words, modernity can enlighten us, and it can disempower us, which is reflected in various different literary works written in the $18^{\text {th }}$ century. The narratives of sociology also reflected different ways of understanding paradoxes such as commitment vs. freedom; structure vs. agency. For example, Weber, one of the fathers of sociology, is known as a thinker who tried to solve the puzzle of modernity by offering us concepts such as enchantment and disenchantment of the world, as an 
outcome of rationalization. Modern societies, he claimed, opened up ways for establishing institutions resulted in people becoming very disenchanted. That is, people not only benefited from the rational methods and tools of modernity, but also felt as if they were living in an "iron cage". These kinds of metaphors used by Weber and others helped the discipline of sociology to narrate its own claims in a clear way. After all, if sociology was to explain, understand, and describe certain patterns of actions of individuals and institutions, this could have been possible through numbers as well as narratives. The social world in which people felt disenchanted created different forms of crises some of which were related to questions of morality. If people living in an iron cage were experiencing this dilemma between freedom and commitment, the void that modernity created could be filled by religion, morality, culture, and other means; all of which offer us different narratives. By definition, people living in modern societies are capable of reflecting on themselves as well as others through knowledge about humanity or society. This knowledge, which usually derives from science, can help them to understand themselves as well as others. From time to time they also use their common sense to reflect on themselves to resolve conflicts brought about by the process called 'disenchantment with the world'. The (personal or collective) narratives about our lives are useful to resolve conflicts, tensions, strains, and moral dilemmas partly constructed by society. Sociology, therefore, cannot be isolated from the world of narratives by which it is possible to shed light on the society as well as others.

What is a narrative? Ewick and Silbey (1995) answer the question as follows: "First, a narrative relies on some form of selective appropriation of past events and characters. Second, within a narrative the events must be temporally ordered. This quality of narrative requires that the selected events be presented with a beginning, a middle, and an end. Third, the events and characters must be related to one another and to some overarching structure, often in the context of an opposition or struggle." 
The ways in which narrative or stories are configured, rely on revealing these characteristics and their sociological significance. Describing and deciphering the details of various different stories can be accepted as acts of creating narrations (Ewick and Silbey, 1995), which have been evaluated by different literary theories and relevant methodological assessments.

One of the points about the narrativity and the literary theory is about the consensus on a wide variety of approaches in narrative theories. Some approaches treat narrative as representation: that is, there are series of events (plot); and focuses on the narrative structure. Other approaches, affected by French structuralism, treat narratives as discourses produced by narrators, still others accept narrative as a verbal act, as a social transaction highly sensitive to social context. In general, social scientists interested in narratives tended to emphasize the traditional meaning of narratives. Polkinghorne argues that "narrative is a meaning structure that organizes events and human actions into a whole, thereby attributing significance to individual actions and events according to their effect on the whole (1998: 18). In other words, stories as part of narratives contribute to the formation of meaning in human imagination. Or, as Frank (2002) writes, "narratability means that events and lives are affirmed as being worth telling and thus worth living (Frank, 2002: 111).

The complex relationship between narrativity and sociology is related to the question of morality. Richard Sennett (1998) argues that character depends on engaging in work that is "legible" in allowing workers to know what they are doing. Sennett finds much contemporary work to be illegible. Stories give lives legibility; when shaped as narratives, lives come from somewhere and are going somewhere. Narrativity offers legibility, and out of both comes a sense of morality, which on a practical ground has an implicit function to show how we should live. In this vein, Bauman's criticism, is worth quoting at length: 
"Numerous studies [none are cited] show that personal narratives are merely rehearsals of public rhetorics designed by the public media to 'represent subjective truths'. But the inauthenticity of the allegedly authentic self is thoroughly covered up by the spectacles of sincerity- the public rituals of in-depth interviews and public confessions of which chat-shows are the most prominent examples, though by no means the only ones. Ostensibly, the spectacles are meant to give vent to the stirrings of 'inner selves' striving to be let out; in fact, they are the vehicles of the consumer society version of a sentimental education: they display and stamp with public acceptability the yarn of emotive states, and their expressions from which the 'thoroughly personal identities' are to be woven" (Bauman, 2000: 86).

By referring to stories, people need to create a higher moral ground which would guide them, especially during crises or stagnation deriving from political problems. People are helped to cope with their personal crises which are expressed as a source of affirmation. In other words, human beings experience struggles and hardships which are eased by the narratives expressed in social environments, some of which provide affirmation of the community. Acts such as public confession, self-expression, and storification all have powerful rhetorical functions with sociological consequences. In other words, different discourses and rhetorical devices which help us to act on others and ourselves are worth to analyze within the framework of sociological themes and problems.

Thus, storytellers may not be aware how their stories carry assumptions embedded in these rhetorics. It seems inevitable that stories will be told in the conventional rhetoric of a cultural context. Social scientists can enlighten the legibility of stories by showing how different types of stories participate in conventional rhetorics. Yet, stories are not what Bauman (2000) calls "merely rehearsals" of these rhetorics. Narrative analysis can show how, even as stories participate in conventional rhetorics, they question the assumptions of the groups whose preferred reality is expressed in these rhetorical 
structures. As stories develop their own preferred rhetoric, narrative analysis can assist in the project of unpacking the assumptions embedded in that rhetoric. Accordingly, the following evaluations will not only offer some insights about the act of narratives, which are mostly mediatized nowadays, but also to present a list of rhetorical tools by which social scientists can analyze the rhetorical features of the narratives.

\section{NARRATIVES, MEDIA AND MEDIATIZATION}

Narratives play an important role in all media texts: films, dramas, commercials, and other genres employ different kinds of narratives, some of which can be accepted as indicators of social phenomena, such as nationalism, modernization, alienation, acculturation, etc. In today's world a wide variety of narratives are expressed and reconstructed through the media, thus transforming our perceptions of narratives into a "mediatized" form. Children listen to the recordings of bed-time stories from podcasts, housewives watch soap operas which include intersections of different narratives, old people watching films which portray the time of their youth from a nostalgic angle, or, some pious people watch televised preaching rituals, where self-appointed religious leaders try to resolve their moral conflicts. In all of these situations, mediatization plays an important role, so as to affect us in a context. The media has taken over the role of other institutions, such as family and school, as providers of information and moral orientation, making it society's most important storyteller about itself (Hjvard 2008).

Schulz suggests that mediatization brings about four types of changes: (1) media extends human communication and interaction beyond immediate time and space, (2) they substitute existing forms of face-to-face communication and interaction, (3) media and existing forms of communication and interaction amalgamate with one another, and (4) social actors and institutions may accommodate to the logic of the media. Broadcasting transforms into narrowcasting. The typical 'mass audience' of the 
television era is dissolving into progressively fragmented audience groups, making use of the new media's net structure for building up 'virtual communities'. Furthermore, the interactivity of the new media turns recipients into communicators ('conversation pattern') (Schulz, 2004). This tendency does not constitute a contradictory argument about the individual narratives as having a strong tie with collective narratives due the the complex relationshp between structrure and agency. The ways in which some narratives are reflections of an agency or agents totally depends on historical, sociological, and cultural boundaries within which discourses and narratives emerge. The postmodern example provided above is certainly relevant fort he age of computer technology whereby people become authors or communicators. Whereas some groups may develop a collectivistic narrative stemming from high levels of social integration in the Durkheimian sense. The examples can be observed from historical moments such as crises, ruptures, and revolutions. The history can offer us reflections about the ways in which fluctuations between agency and structures change over time.

The majority of various different narratives we are exposed at every level reflects the elements of the sociological issues discussed above. People get increasingly depended on media to receive messages, information, knowledge, and narratives, some of which reflect dynamic characteristics of our lives. From time to time, such a dynamic process may turn out to portray a very chaotic and a complicated picture. In this case, stories and rhetorical methods help us to construct meaning making structures: The rich boy gets the poor girl, the poor girl gets the rich boy in many Yeşilçam movies. These rhetorical strategies are used in certain genres constitute their own logic. In other words, the media outlets employ their own "media logic": As Altheide and Snow (1991) argue, the media logic is or has become a dominant way of perceiving social and public affairs. The media logic, they write, consists of a form of communication, the process through which media present and transmit information. Elements of this form include the various media and the formats used by these media. Format consists, 
in part, of how material is organized, the style in which it is presented, the focus or emphasis on particular characteristics of behavior, and the grammar of media communication. Format becomes a framework or a perspective that is used to present as well as interpret phenomena.

In this context, such a mediatized world offers us different layers of narrativity expressed through formats such as reality shows, soap operas, TV dramas or serials, news, films, cartoons, and so on. The media logic used in these programs represents various different sociological divisions based on age, gender, class, nationality, and identity. At this point it is necessary to take a look at the examples presented by the Turkish media.

\section{TURKISH MEDIA AS A SOURCE FOR STORYTELLING PRACTICES}

With the rise of commercial channels in 1980's, TV has become the most significant medium of the entertainment in Turkish society. Television has made it increasingly difficult to harness the dispersal of cultural identities in the public realm. It has been widely argued that developments in globalmedia culture have eroded the state hegemony in the cultural realm and inevitably made the fragmentation and dispersal of the cultural identities (Öncü 2006).

The privatization of the TV channels after the late 1980's reveals the most important process in terms of integrating the Turkish cultural production world into the track of globalized logic of media institutions. These processes include the proliferation of TV channels, the privatization frenzy in institutional sphere of liberalism, the circulation of new genres, the articulation of traditional, modern and postmodern languages into media texts and materials, and struggles over the identity crises at different levels, all of which contributed to the formulation and production of new programs and formats in the media. 
The emergence of the private channels in late 1989 in Turkey symbolized the impact of the globalization on media industries. These channels later became the major actors in meeting the demands of commercial artistry. While the media world had previously been dominated by the TRT (Turkish Radio and Television), which was publicly financed, the developments in the new political economy of the media brought about the elimination of the old genre, as well as the old technological features. The consumption of the media symbols had to be done rapidly, the lay person was able to dream of becoming one of the stars by participating one of the reality shows. The function of the media began to cover a wide spectrum between being an observant / consumer of the media content, and a participant/actor actively involved in making of it. Thus, the media has emerged as a major agent in everyday life revealing mundane, sacred, modern, traditional, hybrid features of various different cultural routines. Additionally, as Erol-Işık (2013) notes, glocalized forms of the genres connected people with the rest of the world by creating a bombardment of programs, which resulted in tendencies to seek for authentic voices. In other words, the more the global modern culture was perceived as a threat for various types of traditional values, the more audiences were offered media texts covering the problems and issues in the very backyard of the society.

\section{EXAMPLES ON RHETORICAL STRATEGIES USED IN ANALYZING NARRATIVES IN THE MEDIA}

There are different strategies we can employ to investigate the role of the narratives in the media. The storytelling practices used in different genres are good examples of this process. The glocalized forms of genres connected people with the rest of the world by creating a bombardment of programs, which resulted in tendencies to seek for authentic voices. In other words, the more the global modern culture was perceived as a threat to various types of traditional values, the more audiences were offered media texts covering the problems and issues in the very backyard of their society. After 2000's, one of the 
most popular genres on the Turkish TV channels became TV serials, which imitated real life situations. The portrayal of the ethnic identities on serials created a possibility for a public discussion. One of the most significant features of the TV serials is the way they create a feeling of continuity in narration by creating a plot in which the beginning and climax of the story are predictable, thus resurfacing the affective role of the narrative in terms of emphasizing curiosity and gazing. Such narrative characteristics promote the audiences' identification with the main characters.

As it is well known, the study of the features of texts is significant in terms of measuring or evaluating the persuasiveness of these texts. One needs to understand how the medium (of TV), content, and the audience come together in a cohesive way. What features of the message have what potential persuasive effects? What information/content has persuasive potential? How does the message and its delivery impact its intended audience?

In this context, the history of the fundamental communication process depends on the rhetorical strategies used by different actors. Rhetoric is the form of communication that organizes the thought and the outcome. Some of the rhetorical strategies are:

Enthymeme (örtük kıyas): A device used to engage an audience based on observation, generalization and inference.

For example, good citizens ought to feel loyalty toward their allies, just as individuals should feel personal loyalty toward their friends.

Such a rhetorical strategy is widely used in mythic discourses where figurative tools are integrated into the discourse of the story.

Ethos: It is defined by moral character, intelligence and goodwill. 
Some characters may be attributed as having prophetic characteristics.

Epideictic rhetoric: Praise or blame speech.

This strategy is highly used by politicians as well as heroic characters.

The theory of rhetorical communication offers many opportunities (e.g., irony, euphemism, allegory, metaphor, synecdoche, trope, alliteration, etc.) for social scientists as well as literary specialists in delineating tools to investigate issues such as:

- Who has power over others?

- Who sets the agenda?

- Who is in charge?

- Who is the author of the text?

- Who is/are silenced?

- Who are excluded/included?

- What is the text telling us?

When we answer these questions through narrative and rhetorical strategies, we may as well obtain data on a series of sociological indicators. To provide an example of the power of the narrative, the following statements will present a case from the Turkish media.

Discursive characteristics of storytelling as a folk tradition in Turkish society are articulated into the texts of a popular genre, namely TV drama, the production and distribution of which has increased nationally and internationally in recent years. Although the themes of the TV dramas vary, a great majority of which incorporate characteristics of the old classical Turkish movies, such as melodrama. Love and lust, action and heroism, vengeance and glorification, materialism and altruism are among the themes which reflect a negotiation among pre-modern, modern and postmodern ways living. The genre has become so popular that a culture industry has emerged and started marketing products 
providing the sensational reflections about the ambivalences of Turkish modernity. Some of these have been exported to Middle Eastern countries, as well as Russia, an international role for Turkish dramas. After the domination of foreign TV dramas ended towards the end of 1980's, Turkish productions started creating stories of various different plots and characters: women trying to find rich husbands, the extravagant lives of urban elites, the moral dilemmas of individuals representing different social classes, conspiracy theories and mafia, ethnic tensions, religious stories, and people aspiring to maintain their communal ties in neighborhoods.

Deli Yürek (Crazy Heart) was among the popular TV serials produced and broadcasted in 1998, and it was on the air for four years. The way in which the TV drama is selected is based on narratives included in the texts. The hero of the narrative is Yusuf. The TV serial narrates a story about a very brave young man, Yusuf, who seeks for justice and morality in his life. He lived a normal life until he was recruited by his commander as a special agent to fight against his enemies. Yusuf is brave, charismatic, handsome, genuine, honest, and passionate about a just life; his aim in life is to 'do the right thing'. Yusuf becomes a hero fighting against villains who are also the members of the mafia world. He is surrounded by the negative world of these immoral characters (gangsters, criminals, etc.) on the one hand; and the 'normal' or moral people, his friends, relatives and others, who are living quiet, peaceful lives, on the other. The binary opposition between the positive and the negative worlds is the main theme of the story, which is based on the events and incidences which show that the immoral and criminal world brings about sins and misdeeds. The epideictic character of the narrative dictates the text in a way that praises, exalts or condemns the key characteristics of the heroes and/or villains.

His relationship with his best friend and moral mentor, Kuşçu (the bird man), is key to understanding the aesthetic sensation created the text's utilization of parables. The birdman, who feeds the birds at 
the top of an apartment, is Yusuf's moral guide in resolving all types of dilemmas he experiences in the cruel world of the sinful characters. Yusuf is a powerful man who accepts only the birdman as his interlocutor, with his spiritual powers. His spiritual righteousness is implied in several occasions through the narrative power of his stories, which are designed to act as a force of mediation between the evil and the spiritual world. The birdman, by using his spiritual powers, can make predictions about the future. He dreams about Yusuf's life; he makes implications about the musts of virtuosity in life; but he never openly and directly imposes his caveats which are storified as parables in the serial. The birdman's recommendations are relayed through stories he already knows or he borrows from the proverbs, verses, hymns, mystic figures, verses of spiritual nature, all of which signify folkloric wisdom and telos. Thus, the storytelling is employed to clarify the duality between what is defined as the sinfulness and virtuous. The parables as metaphors serve for constructing a mediated narrative based on morality and piety.

In one of the episodes (64) the following parable is told by the birdman:

The birdman takes care of a wounded bird.

The birdman: How is your wounded bird (his girlfriend)?

Yusuf: She thinks that she'll get better.

The birdman: Good. You love her so much, don't you?

Yusuf: What is 'much'?

The birdman: Good question.

Yusuf: What does it mean?

The birdman: Whose love is greater? Your love? Or her love? Why, do you think? You do not love her as much as she loves you.

Yusuf: What should I say?

The birdman: You are more interested in being loved than herself.

Yusuf seems surprised. 
The birdman: Well, that happens. A moment comes and you start loving being loved. It is more joyful than be in love. Believe me.

Yusuf: How come you comprehend these things?

The birdman: As (the great Turkish Anatolian Mystic Poet of the Late 13th and Early 14th cc) Yunus Emre states: "I climbed up the plum tree and I ate grapes... See that? What are grapes doing in a plum tree?"

Yusuf laughs.

The birdman: What is the relevance? I do not know what the others think; but I interpret it as follows: What sustains a lover (man) is not his beloved; the sustenance is loving itself.

Yusuf agrees.

The birdman: That's why they never nourish themselves with those who think that they are lovers because, they never look at love. What do they do? They consume their lovers...

Yusuf seems confused.

The birdman: The lover never eats up his beloved. Those who do that appear like animals. That's why they end up dying, but lovers live forever.

Yusuf contemplates.

The birdman: Those who die are animals, lovers never decease.

Yusuf: That's a hard lesson, I need to compose myself.

In this narrative, the theme of love is narrated through a multilayered text in which a series of rhetorical tools are utilized. Love as a spiritual and a transcendental condition is narrated via a story by Yunus Emre, which is integrated into the narrative itself. A certain ethos is told so that Yusuf, the hero of the TV drama, can take lessons about himself. There is also an irony created by the Birdman, expecting Yusuf to encouraging Yusuf to elevate himself to a higher level of spiritual awareness. Yusuf, who has been struggling in the criminal world of gangster members, is told a story of an ethos in which metaphors such as 'the tree of wisdom' are used, that the audience can be convinced. Yusuf's naïve role and the telos he has been following are strengthened through these rhetorical devices in the text. The bad guys, the enemies he is fighting against, represent those undermining such an ethos 
formulated by Kuşçu. By listening to the story, Yusuf as well as the audience have the opportunity to be morally elevated, due to the character of the story. Yusuf, who experiences conflicts and strains, consults his mentor, who acts as a mediator for him. Texts such as stories function as a mediator for people who experience moral dilemmas. Yusuf starts reflecting on himself as soon as he hears the story, which concerns the role of reflexivity constructed by the textual tools such as narratives. As is emphasized above, narratives such as parables and myths help us to reflect on the strain between agency and the society.

\section{CONCLUSION}

There are different ways of knowing the world. These different ways of knowing have been debated throughout the history of philosophy. Some argued that knowing is possible through discovery (positivism/rationalism/empiricism), others claimed that knowing is possible through interpretation (hermeneutics), and lastly there have been some approaches based on knowing by criticism (critical theory/semiotics/postmodernism). If we take a close look at the nature of reality, the role of the knower, and the purpose of the research in these different epistemological paradigms, we can easily understand that there are different questions posed in each paradigm which have been answered differently. For example, knowledge by interpretation assumes that there are multiple realities that are socially constructed. Reality is interpreted from the standpoint of a knower. The process of interpretation is creative and value laden; and the purpose of research is to understand how meaning are created (Merrigan and Huston, 2004).

Accordingly, the intersection of sociology and literary studies has always been interesting in terms of revealing dynamic details of social life narrated via stories, parables, and other textual material. Sociology, as the science of society, is interested in both structures and agency, which are interrelated at micro and macro levels. The everyday life of lay people is full of stories which reflect the role of 
structures, such as institutions (religion, economy, politics, etc.) as well as their intentions about their social actions. We are subjects who are exposed to the power of these institutions; and at the same time, we express our subjectivity in the process of subjectification. This is why great authors such as Tolstoy, Chekov, Tanpinar, Atay and others were able to shed light on the ways in which such complex processes as subjectification/objectification; structuration/agency; alienation, submission, or revelation could be perceived at every moment in modern life. This is why we learn (through interpretation) various different feelings as well as cognitive elements when we read novels such as Martin Eden by Jack London, or Saatleri Ayarlama Enstitüsü by Tanpınar. The rhetorical tools used in these narratives can reveal the dynamic between society and individual. The narratives are formulated at different levels: fiction and non-fiction; novels and stories; some of which are appropriated by the media, which use different methods to integrate the literary descriptions, as in the old Yeşilçam movies. The recent productions include re-adaptations of Turkish novels such as Aşk-1 Memnu, Yaprak Dökümü, Yılanların Öcü, Kurt Seyit and Shura. The TV drama, which became very popular after the privatization of TV channels, especially re-adapted old mythic genres and characters, as well as heroic stories. TV drama as a genre not only adapted folkloric narratives, but also created a language in which different stories could be re-assembled in a new fashion. Thus, the story of Deli Yürek itself opened up new possibilities for the act of storytelling, and was also related in other venues (commercials, news stories, etc).

The story told by the Birdman in the text of Deli Yürek can enlighten the audience by directing their thoughts towards their subjectivity which is controlled by spiritual forces, fate, or other unknown forces. Or, the same story can shed light on the ways in which love is constructed by the beloved, who also lives in a society. Such stories as parables cannot be seen merely as moral lessons; they are also cognitive guidelines for people enabling them to act on themselves. In other words, the literary work 
can empower us in terms of providing some maps for our subjectivity or agency. Thus, the storytelling, which is mediatized, is employed to clarify the duality between what is defined as sinful and virtuous. The parables as metaphors serve for constructing a mediated narrative based on morality and piety.

In sum, new areas of investigation seem to have emerged for both sociologists and literary analysts in terms of evaluating different angles and layers of textual materials such as fiction, stories, parables, myths, and others. Narrativization has been an important characteristic observed in media texts, politicians' discourses, economic reports, children's books, films, popular religion, TV drama, and other spheres of social life. Rhetorical and discursive characteristics of these texts can enlighten sociological realities, such as class divisions, exclusion/inclusion, social structure, community life, identity, and other themes. The discipline of sociology has long been interested in resolving the dilemmas between structure and agency, as well as individual and community. Sociology has been a discipline focusing on individuals living in society, that is, social institutions and social structures. The patterns of relationships we are involved with require a series of clearly defined and meticulous descriptions which have been narrated by various pioneers of Turkish sociology (Berkes, Ülken, Kıray, Yasa, Mardin, and others). Turkish folklorists, as well as literary scholars have also attempted to shed light on different aspects of the social reality. What is needed at this moment are further innovative and interdisciplinary studies which would bring together different traditions of interpreting the world, so as to provide greater insights into the increasing wordlessness about the world itself. 


\section{ÖZET}

$\mathrm{Bu}$ makalede amaç anlatı ve öykü adı verilen dilbilimsel verilerin sosyoloji disiplini için önemini değerlendirmektir. Anlatıya dayanan metinlerin bilimsel veri olarak kabul edilebilmesi ile ilgili epistemolojik tartışmalardan çok, gündelik hayatta pekçok farklı mecrada karşılaştığımız öykü, efsane, kıssa, ironi, fikra, drama, aforizma gibi örneklerin sosyal hayat hakkında oluşturduğumuz anlam dünyası ile ilgisine dikkat çekmek hedeflenmektedir. Sosyoloji, toplumsal hayat ile ilgili farklı eksenlerde çözümlemeler yapan bir bilim dalı olarak anlatıya dayanan verilerden farklı şekillerde faydalanabilir. $\mathrm{Bu}$ anlamda anlatı ile sosyolojinin biraraya gelme biçimi sosyolojiye bakış tarzımızla da ilgili olacaktır. Sosyolojik teorilerden önce sosyal teorilerin atıfta bulunduğu anlatı ve söylem dünyası gerek birey gerekse toplumsal düzlemde çeşitlilik sunan malzemeler ile bezenmiştir.

Günümüzde medya aracıllı̆ı ile 'öyküleştirilen' anlatılar bireylerin anlam dünyaları üzerinde oldukça önemli bir etkiye sahiptir. Ninnilerin anlatı açısından önemi nasıl bir annenin kişisel tercihinden bağımsız olarak kolektif referanslara sahip olduğu kadar, tarihsel toplumsal hafızamızda yer etmiş büyük anlatılar da bir o kadar derin katmanlar taşıyabilen niteliktedir. Öyküler ve öykü-anlatımı, toplumsal hafızanın enbelirgin gösterenlerinden biridir ve toplumsal imgelem ile ilgili önemli ipuçları sunar. Romanlar da sosyolojinin çekirdek ikiliklerinden biri olan fail ve yapı arasındaki ilişkinin karmaşıklığını aydınlatan önemli veriler olarak kabul edilebilir. Buna göre, farklı anlatımsal araçlar bireylerin toplumda nasıl konumlandıklarını anlamamıza yarayan önemli metinsel veriler arasında yer alır. Kısaca, makalede öncelikle anlatı kuramı ve sosyolojinin kesişme noktası aydınlatılacak, daha sonra da öyküleştirme örneklerine dayanan popüler kültürel metinlerden örneklerle aydınlatılacaktır. 


\section{REFERENCES}

Altheide, D. L., Snow, R.P. (1991). Media Worlds in the Postjournalism Era. New York: Aldine de Gruyter.

Andrews, M. et al. (2009). The Uses of Narrative: Explorations in Sociology, Psychology, and Cultural Studies. New Jersey: Transaction Publ.

Barthes, R. (1977). Elements of Semiology. Farrar, Straus and Giroux: Paris.

Bauman, Z. (2000). Liquid modernity. London: Polity Press.

Erol-Işık, N. (2013). Parables as Indicators of Popular Wisdom: The Making of Piety Culture in Turkish Television Dramas. European Journal of Cultural Studies. 16(5): 565- 581.

Ewick, P., Silbey, S. (1995). Subversive Stories and Hegemonic Tales: Toward a Sociology of Narrative. Law and Society Review, Vol 29(2): 197-210.

Frank, A.W. (2002). Why Study People's Stories? The Dialogical Ethics of Narrative Analysis. International Journal of Qualitative Methods. 1(1): 27-46.

Franzosi, R. (1998). Narrative Analysis or Why (and How) Sociologists Should be Interested in Narrative. American Review of Sociology. 24: 517-54.

Game, A., Metcalfe, A. (1996). Passionate Sociology, London: Sage.

Hjvard, S. (2008). The Mediatization of Religion: A Theory of the Media as Agents of Religious Change. In Northern Lights: Media Studies Yearbook, 6(1):9-26.

Maines, A. (1993). Narrative's Moment and Sociology's Phenomena: Toward a Narrative Sociology. The Sociological Quarterly, 34(1): 17-38.

Merrigan, G., Huston C. L. (2004). Communication Research Methods. Wadsworth Pub Co.

Öncü, A. (2006). Becoming secular muslims: Yaşar Nuri Öztürk as a super-subject on Turkish television. Meyers, Birgit and Moors, Annelies (Ed.), Religion, Media and the Public Sphere içinde (s. 227-240), Indiana, Indiana University Press.

Poletta, F. et al (2011). The Sociology of Storytelling. Annual Review of Sociology, 37: 109-130. 
Schulz, W. (2004). Reconstructing Mediatization as an Analytical Concept. European Journal of Communication, 19: 87-100. 